\title{
Dark Triad, Counterproductive Work Behaviors, Workplace Incivility, and the Role of Islamic Work Values: A Moderated Mediation Model
}

http://doi.org/10.21272/bel.4(4).56-67.2020

Muhammad Salman Chughtai, ORCID: https://orcid.org/0000-0002-6117-9070

$\mathrm{PhD}$ Scholar, Faculty of Management Sciences, International Islamic University, Islamabad, Islamic Republic of Pakistan

Dr. Hira Salah Ud Din Khan, ORCID: https://orcid.org/0000-0002-7130-6897

Post-Doctoral Fellow, School of Management, Jiangsu University, Peoples Republic of China

Dr. Syed Zulfiqar Ali Shah, ORCID: https://orcid.org/0000-0002-5256-3003

Associate Professor, Faculty of Management Sciences, International Islamic, University, Islamic Republic of Pakistan

Lenny Yusrini, ORCID: https://orcid.org/0000-0001-9126-0753

Assistant Professor, Akademi Pariwisata Indonesia (AKPINDO), Jakarta, Republic of Indonesia

\begin{abstract}
The organization's ethical climate increases productivity at the individual the organizational level; further, it reduces the harmful characteristics and negative intensity of individuals' inflated self-esteem. Integration of the theory of threatened egotism and ethical climate theory, this study's objective was to examine the mediating mechanism of workplace incivility between dark triad (Narcissism, Psychopathy and Machiavellianism) and counterproductive work behaviors with the sample from public sector (judiciary) institution. Additionally, in the present study, we also test the moderating effect of Islamic work values between the mediating relationship of workplace incivility and counterproductive work behaviors. Close-ended questionnaires were used to collect data from a sample size of 268 participants (permanent employees of the judiciary) of a public sector organization who voluntarily participate in the process of data collection for this study. To test the study's proposed hypothesis, different statistical techniques, i.e., correlation, regression were applied to test the direct effects, and Hayes PROCESS-macro method was applied to test indirect effects (mediation), moderation, and moderated mediation. Findings of the study indicate that workplace incivility mediates the association of dark triad and counterproductive work behaviors. Furthermore, findings reveal that Islamic work values moderate the mediated relationship between workplace incivility and counterproductive work behaviors. We also tested the moderated mediation model, and findings indicate that Islamic work values weaken the positive intensity of dark triad and counterproductive work behaviors in the presence of workplace incivility. This study's findings further declare that a higher level of Islamic work values weaken the intensity of negative personality on counterproductive work behaviors and decrease the uncivil behaviors of individuals at the workplace. Policymakers and higher management of public sector institutions especially focus on the psychological health and organizational climate to reduce the workplace's harmful behaviors. Finally, this study theoretically enhances knowledge of personality psychology literature by explaining the negative consequences of negative personalities at the workplace. Overall, this study contributed to the theory of threatened egotism and ethical climate theory by integrating dark triad, workplace incivility, counterproductive work behaviors, and Islamic work values collaborations with exciting outcomes, specifically with the background of public sector institution of Asian developing country.
\end{abstract}

Keywords: Dark Triad; Workplace Incivility; Islamic Work Values; Counterproductive Work Behaviors; Theory of Threatened Egotism; Ethical Climate Theory.

JEL Classification: M1, M54, M140.

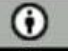

This work is licensed under a Creative Commons Attribution 4.0 International License

Cite as: Chughtai, M.S., Khan, H.S.U.D., Shah, S.Z.A., Yusrini, L. (2020). Dark Triad, Counterproductive Work Behaviors, Workplace Incivility, and the Role of Islamic Work Values: A Moderated Mediation Model. Business Ethics and Leadership, 4(4), 56-67. http://doi.org/10.21272/bel.4(4).56-67.2020.

(C) The Authors, 2020. This article is published with open access at Sumy State University. 


\section{Introduction}

Individual and organizational performance is mainly dependent on humans' behaviors and personality characteristics (De Dreu \& Nauta, 2009). Negative personality holder creates a noxious atmosphere that disadvantageous for the organization and society and affects the individuals' performance, physical and psychological health (Simonet et al., 2018). The quality of social relations plays a remarkable role in individuals' well-being at the workplace, whereas negative social relationships show discomfort, fatigue, or intention to quit (Cortina \& Magley, 2009; Lim et al., 2008). Scholars noted that public sector organizations face uncivil and destructive behavior (Sguera et al., 2016). These organizations encountered counterproductive work behaviors (CWBs) that include verbal abuse, theft, and sabotage (González-Navarro et al., 2018) that ultimately harm the organizational system. Recently, researchers have identified that certain noxious personalities that usually exist in the public and private organizations and characterized as a dark triad (DT) (Paulhus \& Williams, 2002), which contains "Machiavellianism, narcissism, and psychopathy". Specifically, DT reflects an "ambiguous" view of employee behavior and represents negative work-related results (O'Boyle et al., 2012). Studies on DT have shown that these personalities are linked with aggression (Jones \& Paulhus, 2011). Scholars explained that aggressive conduct, lack of cooperativeness, unethical behavior, and negative emotions at the workplace are part of CWBs (Cohen, 2016; Jones \& Paulhus, 2011; O'Boyle et al., 2012). Numerous studies have endeavored to find out the antecedents of CWBs, and it was found that DT causes negative behaviors at the workplace, i.e., CWBs (Özsoy, 2018). Workplace incivility (WPI) is one of the significant predictors of negative outcomes, i.e., CWBs (Schilpzand et al., 2016; Welbourne \& Sariol, 2017) as uncivil behavior is a common phenomenon that is well acknowledged (Andersson \& Pearson, 1999). Previous studies have focused on WPI to understand the consequences that are related to economic, social, physical, and psychological (Bai et al., 2016; Porath \& Pearson, 2013), and highlighted that ignoring WPI can be harmful to both organizations and employees (Schilpzand et al., 2016). Despite the high prevalence and costs of WPI, little research explains what causes WPI in the organization (Schilpzand et al., 2016), which needs further investigation.

The present study emphasizes ethical values of work from Islamic values originating from the Holy Quran, practical life, and sayings of Prophet MUHAMMAD (SAW) (Ali \& Weir, 2005; Rizk, 2008). Scholars ordained that Islamic work values increases individuals' motivational level (Nasution \& Rafiki, 2019) and reduces negative outcomes such as WPI. Islam talks about all life domains, i.e., economy, society, physical and psychological health (Ahmad, 2011). Previous studies have highlighted that IWVs play a significant role in attaining positive outcomes from individuals at the workplace (Mohammad et al., 2016). Additionally, IWVs stresses forgiveness, selflessness, equality, and cooperation among humanity (Quoquab \& Mohammad, 2013) that would likely decrease negative behaviors such as WPI and CWBs. In a nutshell, this study's foremost aim is to analyze the intervening role of WPI on the DT - CWBs relationship and the moderating role of IWVs on the WPI - CWBs relationship. First, we examine how WPI affects the association of DT - CWBs. Second, we argue that IWVs could weaken the association between WPI and CWBs. Third, while WPI has been studied mainly in western countries, we explored its consequences in the culture of a developing Asian country, Pakistan. Fourth, this research answers the call for research (Liu et al., 2020; Mackey et al., 2019; Shin \& Hur, 2019) by investigating the influence of DT on CWBs via WPI as a mediator and IWVs as a moderator by infusing the theory of threatened egotism (Baumeister et al., 1996; Bushman \& Baumeister, 1998) and ethical climate theory (Victor \& Cullen, 1987, 1988).

\section{Hypothesis Development}

2.1 Dark Triad and Counterproductive Work Behaviors. Paulhus and Williams (2002) first time elaborated on the dark personality behaviors that are termed as the DT. Researchers have indicated that personalities who score high on dark features are found to be in better positions to accumulate critical resources from the environment (Smith et al., 2018). Psychopathic personalities hold the qualities which include egotistical and deceptive interpersonal communication, lack of emotional experience, low sensitivity, lack of responsibility or sorrow, impulsive and immature behavior (Cohen, 2016; Paulhus \& Williams, 2002), resulting in selfish, proud, and unreliable social relations (Jakobwitz \& Egan, 2006). Narcissistic people usually use harmful tactics to degrade others, strive to create an impression on others, hold egoistic behavior, and self-centered (Paulhus \& Williams, 2002). Similarly, Machiavellianism is based on adopting devious communication strategies with others and sensitive social enchantment (Paulhus \& Williams, 2002). Individuals on a higher level of Machiavellianism are likely to exploit others (Abas et al., 2015) and are less concerned about benefitting others (Jakobwitz \& Egan, 2006). CWBs may include interpersonal violence, sabotage, theft, and confiscation (Spector \& Fox, 2002, 2005). The working atmosphere of public sector organizations, especially in developing countries, is challenged with low self-esteemed personalities that increase negative emotions and attitudes 
(Costello \& Dunaway, 2003), i.e., WPI and CWBs (Brender-Ilan \& Sheaffer, 2019; Penney \& Spector, 2002). Theory of threatened egotism (Baumeister et al., 1996; Bushman \& Baumeister, 1998) proposed that due to high perception of threat from the society about the ego of dark personalities (Konrath et al., 2006) and low morale (Baumeister et al., 1996; Bushman \& Baumeister, 1998), these traits behave aggressively and negatively at the workplace to shield their superficial appearance of self-confidence (Stenason, 2014) in front of others. Even though prior studies have been conducted on DT and CWBs, there is still a need to investigate other DT's impact in different work settings (Braun, 2017; Volmer et al., 2016). In response to these calls, we explore this in a relationship in a developing country; thus, we hypothesize that:

H1 DT positively relates to CWBs.

2.2 Workplace Incivility as Mediator. WPI is concerned with a lack of enthusiasm at the workplace in terms of social exchange in the form of mutual social disagreement (Andersson \& Pearson, 1999). A recent study revealed that dark personalities, i.e., narcissism, psychopathy, and Machiavellianism, predict low-intensity workplace uncivil behavior, i.e., WPI (Lata \& Chaudhary, 2020). Additionally, O'Boyle et al. (2012) stated in their meta-analytic study that dark personalities are usually engaged in CWBs, i.e., aggression, WPI, and bullying (Wu \& Lebreton, 2011). Moreover, the study of Schilpzand et al. (2016) endorsed a positive relationship between WPI and CWBs. Previous research revealed that WPI generates undesirable values that affect physical and psychological health, which eventually leads to decreased job satisfaction (Chen \& Wang, 2019), commitment (Pearson \& Porath, 2005), OCB (Porath \& Pearson, 2013). Conversely, numerous studies indicated that employees who suffer from incivility exhibit job dissatisfaction, high job anxiety, and distress (Bai et al., 2016; Cortina \& Magley, 2009; Lim et al., 2008). For instance, Karim et al. (2015) depicted that WPI mediates the relationship between emotional intelligence and work-related outcomes, i-e., CWBs, and turnover intention. Thus, by using the theoretical lens of the theory of threatened egotism (Baumeister et al., 1996; Bushman \& Baumeister, 1998), we examine the intervening mechanism of WPI that increases the intensity of DT and CWBs; thus, we hypothesize that,

H2 WPI positively mediates the relationship between DT and CWBs.

2.3 Islamic Work Values as Moderator. Islamic values are synthesized from the Qur'an, the lessons, and teachings of the Prophet MUHAMMAD (SAW), along with the traditions set by the four Islamic Caliphs (Ali \& Weir, 2005; Rizk, 2008). Islamic ethical values comprise of economic, psychological, and societal elements. Ahmad (2011) stated that work is vital for individuals and society as well. Scholars elucidated that individuals' motivational levels can be enhanced by following the IWVs (justice, morality, kindness, and trust) (Nasution \& Rafiki, 2019), as IWVs refrains from abuse, egoism, and negative behaviors, i.e., incivility at the workplace. The ethical environment is closely related to employees' positive behaviors (Wang \& Hsieh, 2013) that gives a perception to employees about the fair dealings and the organization's proper handling of matters (Victor \& Cullen, 1987, 1988). Islamic work values enhance employees' performance and positive behaviors; reduce egoistic and uncivil behaviors of individuals (Chughtai et al., 2020; Suryanto, 2016). Studies have substantiated that IWVs provides an ethical climate to the organizations that help reduce adverse outcomes of the individuals, i.e., abusive supervision, CWBs, and knowledge hiding behavior (Hayati et al., 2018; Khalid et al., 2018). Additionally, the literature shows that numerous studies found moderation of Islamic work ethics in various organizational contexts with the different relationship of different variables (Ahmed et al., 2019; Chughtai, 2017; Chughtai \& Ali Shah, 2020; Mohammad et al., 2016; Qayyum et al., 2018). Through the lens of ethical climate theory (Victor \& Cullen, 1987, 1988) we explain the moderating mechanism of IWVs as how harmful effects of WPI on CWBs mitigated. Besides this, Shin and Hur (2019) called for future research and suggested to test potential moderators between the relationship of WPI and employees' outcomes. Thus, we hypothesize that,

H3 IWVs moderates the positive mediating association of WPI and CWBs such that the positive relationship will be weaker at a higher level of IWVs.

$\mathrm{H4}$ The indirect effect of DT on CWBs via WPI will be weaker when the level of IWVs will be higher. 


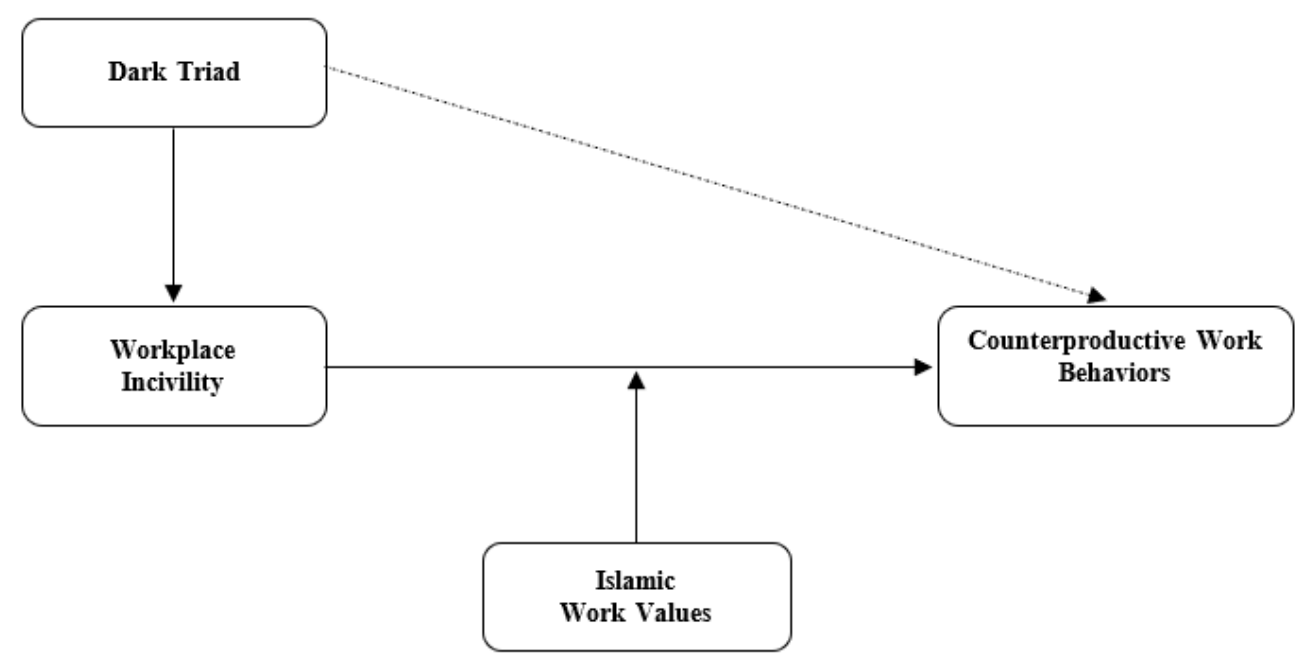

Figure 1. Conceptual Model

Source: Based on empirical research gap (Liu et al., 2020; Mackey et al., 2019; Shin \& Hur, 2019)

\section{Methodology}

3.1 Sample and Procedure. Data were collected from permanent employees (office coordinator, senior office coordinator, and admin office coordinator) of a public sector institution (Lahore High Court), Punjab, Pakistan, to test the formulated hypotheses. Purposive sampling technique was used because the intention behind the selection of this sampling technique was that through this technique, researchers utilized their resources to gather information from the target population efficiently and effectively in such a way that it achieves the aims and objectives of the research through the right participants who hold the information related to our study constructs. (Campbell et al., 2020; Etikan et al., 2016). Before the collection of data, respondents were well acquainted with the intention and effectiveness of the study. 350 questionnaires were distributed amongst Lahore High Court employees, Punjab, Pakistan; 268 respondents completed questionnaires correctly, forming the response rate of $76.57 \%$. Since the data of this study was collected from a single source through selfadministered data collection technique, so Herman's (1967) single-factor analysis was conducted to test the CMV; the cumulative percentage value of extraction sum of squared loadings was $21.62 \%$, which was less than $50 \%$ which shows that there was no problem of CMV in data.

3.2 Measurement Tools. The CWBs scale was measured using a 5-points Likert scale ranging from "Never" to "Every day". Remaining all variables DT, WPI, and IWVs were measured using a 5-point Likert scale ranging from "Strongly Disagree-1" to "Strongly Agree-5". The dark triad was measured via 27-items (nineitems for each dimension, i.e., narcissism, psychopathy, and Machiavellianism) scale (three-items from each dimension remove which were not matched with the social context of the sample) taken from Jones \& Paulhus (2014). Counterproductive work behaviors (Withdrawal and Abuse ) were measured using 22-items taken from Spector et al. (2006). Workplace incivility was analyzed by taking a 7-items scale (two-items remove, which were not matched with the sample's social context) taken from Cortina et al. (2001). Islamic Work Values were analyzed by taking a 12-items (Benevolence and Cooperation) scale adopted from Wahab et al. (2016).

\section{Results}

Out of 268 respondents, 237 (88.4\%) were male, and $31(11.6 \%)$ were female. $42.5 \%$ of participants belonged to an age range of "20-30 years", and 39.6\% belonged to "31-40 years". Education-wise, $10.4 \%$ holds "intermediate," $25.7 \%$ holds "graduation", and $49.6 \%$ holds "masters" education. $23.60 \%$ of participants having "less than 1-year experience", $23.60 \%$ having " $1-5$ years", $17.30 \%$ having " $6-10$ years", $12.50 \%$ having "11-15 years", $10.30 \%$ having "16-20 years" and $12.50 \%$ having more than 21 years working experience. $42.54 \%$ of participants were "office coordinators", $36.19 \%$ were "senior office coordinator," and $21.27 \%$ were "admin office coordinator" by their designation. $36.19 \%$ of participants were from 'Lahore', $26.87 \%$ were from 'Multan', $21.27 \%$ were from 'Rawalpindi,' and $15.67 \%$ were from 'Bahawalpur.' Table 1 depicts the correlations, descriptive, and reliability statistics, where all variables significantly correlated, but no statistically significant correlation was found between DT and IWVs $(r=-.035, \mathrm{n} . \mathrm{s})$. 
Table 1. Descriptive Statistics, Correlations, and Reliability

\begin{tabular}{|c|l|c|c|c|c|c|c|}
\hline & Variables & Mean & SD & $\mathbf{1}$ & $\mathbf{2}$ & $\mathbf{3}$ & $\mathbf{4}$ \\
\hline $\mathbf{1}$ & DT & 2.93 & 0.425 & $\mathbf{( . 7 3})$ & $.270^{* *}$ & -.035 & $.139^{*}$ \\
\hline $\mathbf{2}$ & WPI & 1.94 & 0.746 & & $(.84)$ & $-.338^{* *}$ & $.225^{* *}$ \\
\hline $\mathbf{3}$ & IWVs & 4.28 & 0.541 & & & $(.89)$ & $-.304^{* *}$ \\
\hline $\mathbf{4}$ & CWB & 1.55 & 0.643 & & & $(.94)$ \\
\hline$* p<0.05 ; * * p<01 ; N=268 ;$ Reliability Statistics are in parenthesis & & & \\
\hline
\end{tabular}

Source: Compiled by the authors

Table 2 displays the hierarchal regression statistics of this study; wherein Model 2, DT significantly and positively influencing CWBs where $(\beta=.209, \mathrm{p}<.05)$, in Model 3 WPI also significantly and positively impacting CWBs where $(\beta=.172, \mathrm{p}<.001)$; thus, it proves our $\mathrm{H} 1$.

Table 2. Unstandardized Direct Path Coefficients

\begin{tabular}{|l|c|c|c|}
\hline \multirow{2}{*}{ Variable } & \multicolumn{2}{c|}{ CWBs } \\
\cline { 2 - 4 } & Model-1 & Model-2 & Model-3 \\
\hline Intercept & $1.608^{* * *}$ & $1.012^{* *}$ & $.961^{* * *}$ \\
\hline Gender & -.100 & -.090 & -.107 \\
\hline Age & -.083 & -.079 & .045 \\
\hline Education & .032 & .018 & .011 \\
\hline Experience & .030 & .036 & .016 \\
\hline Dark Triad & & $.209 *$ & $.172^{* * *}$ \\
\hline Workplace Incivility & & & .055 \\
\hline$R^{2}$ & .007 & .025 & .037 \\
\hline Adjusted $R^{2}$ & .008 & .007 & $3.028^{* *}$ \\
\hline$F$ & .454 & $1.368^{* *}$ & $268 ; *<.05 ;$ \\
\hline
\end{tabular}

Note: DT, dark triad, WPI, workplace incivility, IWV, Islamic work values, CWBs, counterproductive work behaviors, $N=268 ;{ }^{*} p<.05$;

$* * p<.01 ; * * * p<.001$

Source: Compiled by the authors

Table 3 illustrate the mediation statistics of this study by following Hayes (2018) bootstrapping method with 5000 sample; where values of the indirect effect of WPI between the relationship of DT and CWBs was significant because there was no zero between containing between LL and UL values (Effect=.08, $\mathrm{LL} / \mathrm{UL}=.02 / .19$ ) with $95 \% \mathrm{CI}$. We also apply the rules of the Sobel (1982) test, and values also confirm the $(\beta=.08, \mathrm{z}=2.04, \mathrm{p}<.05)$ mediation of WPI between the relationship of DT and CWBs, so it proves our H2.

Table 3. Mediation Analysis

\begin{tabular}{|l|c|c|c|c|}
\hline & Effect & SE & \multicolumn{2}{|c|}{ LL, UL 95\% CI } \\
\hline Indirect Effect Bootstrapping (Hayes) & .08 & .04 & \multicolumn{2}{|c|}{$.02, .19$} \\
\hline Normal Theory tests (Sobel) & .08 & .04 & $2.04(\mathrm{z})$ & $.04(\mathrm{p})$ \\
\hline
\end{tabular}

Note: DT, dark triad; WPI, workplace incivility; IWVs, Islamic work values; CWBs, counterproductive work behaviors; LL \& UL CI, lower-and upper-class interval

Source: Compiled by the authors

Table 4 demonstrates the moderation results, where interaction (WPI $x$ IWVs) values are $(\beta=-.39, p<.001)$; according to moderation interaction higher level of IWVs weakens the positive strength of the relationship between WPI and CWBs. Thus, it proves H3.

Table 4. Moderation Analysis

\begin{tabular}{|c|c|c|c|c|c|}
\hline \multirow{2}{*}{ Moderation Model } & $\mathbf{R}^{\mathbf{2}}$ & $\mathbf{R}^{\mathbf{2}}$ - Change & $\boldsymbol{F}$ & $\mathbf{p}$ & \\
\cline { 2 - 6 } & 0.18 & 0.07 & 11.59 & 0.00 & \\
\hline Interaction Term & Coefficient & $\mathbf{S E}$ & $\mathbf{t}$ & $\mathbf{p}$ & $\mathbf{L L , ~ U L}$ \\
\hline \multicolumn{1}{|c|}{ Constant } & 1.5 & .03 & 47.41 & .00 & $1.44,1.56$ \\
\hline WPI $\rightarrow$ CWBs & .15 & .05 & 3.13 & .00 & $.06, .24$ \\
\hline IWVs $\rightarrow$ CWBs & -.18 & .09 & -2.15 & .03 & $-.35,-.02$ \\
\hline WPI $x$ IWVs & -.39 & .11 & -3.65 & .00 & $-.60,-.18$ \\
\hline
\end{tabular}

Note: DT; dark triad, WPI; workplace incivility, IWV; Islamic work values, CWBs; counterproductive work behaviors; LL \& UL CI, lower- and upper-class interval

Source: Compiled by the authors

Table 5 depicts that both \pm SD values were significant, and there was no zero found between the value of upper and lower bootstrap CIs. Moreover, Table 5 represents the moderated mediation values, where (Index $=-.18, \mathrm{SE}=.07$, $\mathrm{LL} / \mathrm{UL}=-.36 /-.07)$, which proves that IWVs weakens the relationship of DT and CWBs in the presence of WPI; therefore, it proves $\mathrm{H} 4$. 
Table 5. Moderated Mediation Index

\begin{tabular}{|c|c|c|c|c|}
\hline \multicolumn{5}{|c|}{ Conditional Indirect Effect $(D T s$ as IV and CWBs as DV) } \\
\hline Mediator & IWVs (Moderator) & Effect & Boot-SE & LL, UL \\
\hline WPI (-1 SD) & -.54 & .16 & .06 & $.06, .31$ \\
\hline WPI (+1 SD) & .54 & -.04 & .04 & $.13, .02$ \\
\hline \multicolumn{7}{|r|}{ Moderated-Mediation Index (Islamic Work Values as Moderator) } \\
\hline \multicolumn{7}{|r|}{ Index } & Boot-SE & LL, UL \\
\hline Workplace Incivility (Mediator) & -.18 & .07 & $-.36,-.07$ \\
\hline
\end{tabular}

Note: DT; dark triad, WPI; workplace incivility, IWV; Islamic work values, CWBs; counterproductive work behaviors, LL \& UL CI, lowerand upper-class interval

Source: Compiled by the authors

\section{Discussion and Conclusion}

The present study first uncovers that DT has an indirect effect on CWBs of employees through WPI. Secondly, this study also revealed the significant moderating role of IWVs in the relationship between WPI and CWBs. Thirdly, we also found that the indirect effect of the DT on employee's CWBs via WPI was also weak when individuals hold a higher level of IWVs. The first hypothesis of this study predicted a direct relationship between DT and CWBs, and the findings of this study proved $\mathrm{H} 1$ and were consistent and supported by previous studies (Cohen, 2016; Jones \& Paulhus, 2011; O’Boyle et al., 2012). As dark personalities perceive that their ego will be threatened (Baumeister et al., 1996; Bushman \& Baumeister, 1998) from their peers, juniors, or seniors, so they demonstrate aggressiveness. The second hypothesis of this study predicted that WPI mediates the relationship between DT and CWBs. The study's findings indicated workplace incivility indirectly causes negative outcomes for employees at the workplace, i.e., CWBs, which proves $\mathrm{H} 2$, as these results are consistent with earlier studies (Karim et al., 2015). The third hypothesis of this study predicted that IWVs moderates the relationship between WPI and CWBs, and the findings of this study prove H3, and these findings are also supported by previous studies (Ahmed et al., 2019; Chughtai \& Ali Shah, 2020; Wahyuningsih et al., 2019). Finally, the fourth hypothesis unveiled the moderated mediation effect of IWVs between the indirect effect of the DT and CWBs via WPI. The study's findings illustrate that IWVs moderates the mediated relationship of the DT and CWBs via WPI.

5.1 Theoretical Contributions. These study findings provide new insights into personality psychology literature by elucidating the mechanisms, i.e., WPI in the link between DT and CWBs, that explain how individuals' WPI serves as a vehicle aggravating the negative behaviors in the form of CWBs. Our findings revealed that dark personalities react negatively in WPI, as they feel a threat to their ego and protect their image at the workplace. Furthermore, our work contributes to the literature of ethics by infusing ethical climate theory (Victor \& Cullen, 1987, 1988) and moderating the role of IWVs that reduces the egoistic nature of dark personality's leads to aggressive and harmful behavior. Through the lens of the threatened theory of egoism, the findings of this study suggest that reactions of dark personalities in the shape of WPI might be less harmful when they have a higher level of IWVs, that serve as strong faith, the culture of positive norms and atmosphere in the organization reduces the negativity of the individuals.

5.2 Managerial implications. The present study provides some practical, beneficial consequences for the organizations:

The management of the organizations must scrutinize the activities that generate uncivil behaviors and affect efficiency.

$>$ The management must apply different psychological trials to realize individuals' personality traits during the recruitment process.

$>$ To overcome such unethical and uncivil behaviors, (Gulerdg, 2020: 54).

$>$ The present study suggests that organizations could conduct workshops or seminars on ethics-related topics to eschew uncivil behaviors (Leiter et al., 2011).

> Management formulates standard policies to eliminate malicious activities and promote Islamic work values that produce a workplace environment of mutual respect, kind-heartedness, teamwork with others (officer and peers), and reduce destructive activities.

5.3 Future Research Directions and Limitations. The present study has some limitations, which are as follows. First, this study is conducted in one Muslim state, i.e., the Islamic Republic of Pakistan; thus, we suggest that future studies explore the impact of Islamic work values in other Muslim and Non-Muslim countries. Secondly, the present study was conducted in a single public sector organization (Lahore High Court); therefore, we recommend replicating the current model in other cultural setups. Moreover, in this study, 
IWVs was taken as a moderator; future studies can investigate other variables (mindfulness, occupational calling, and emotional intelligence) as possible moderators. Future research may also examine the effects of other situational variables such as positive leadership style, psychological safety climate between the association of dark personalities and CWBs.

Author Contribution. Conceptualization, Muhammad Salman Chughtai; data curation, Muhammad Salman Chughtai; formal analysis, Muhammad Salman Chughtai; investigation, Muhammad Salman Chughtai; methodology, Muhammad Salman Chughtai; project administration, Dr. Syed Zufliqar Ali Shah; resources, Lenny Yusrini; software, Lenny Yusrini; supervision, Dr. Syed Zufliqar Ali Shah; validation, Muhammad Salman Chughtai; visualization, Lenny Yusrini; writing - original draft, Muhammad Salman Chughtai; writing - review \& editing, Dr. Hira Salah Ud Din Khan.

Funding. There is no funding for this research.

\section{References}

1. Abas, C., Omar, F., Wati Halim, F., \& Waheeda, M. H. S. (2015). The Mediating Role of OrganizationalBased Self-Esteem in Perceived Organizational Support and Counterproductive Work Behaviour Relationship. International Journal of Business and Management, 10(9), 99-108. doi:10.5539/ijbm.v10n9p99.

2. Ahmad. (2011). Work ethics: an Islamic prospective. Journal of Human Sciences, 8(1), 850-859. Available at: www.j-humansciences.com/ojs/index.php/IJHS/article/view/1573.

3. Ahmed, A., Arshad, M. A., Mahmood, A., \& Akhtar, S. (2019). The influence of spiritual values on employee's helping behavior: the moderating role of Islamic work ethic. Journal of Management, Spirituality \& Religion, 16(3), 235-263. https://doi.org/10.1080/14766086.2019.1572529.

4. Ali, A. J., \& Weir, D. (2005). Islamic perspectives on management and organization. Journal of Management, Spirituality \& Religion, 2(3), 410-415. https://doi.org/10.1080/14766080509518602.

5. Andersson, L. M., \& Pearson, C. M. (1999). Tit for tat? The spiraling effect of incivility in the workplace. Academy of Management Review, 24(3), 452-471. https://doi.org/10.5465/amr.1999.2202131.

6. Bai, Q., Lin, W., \& Wang, L. (2016). Family incivility and counterproductive work behavior: A moderated mediation model of self-esteem and emotional regulation. Journal of Vocational Behavior, 94, 11-19. https://doi.org/10.1016/j.jvb.2016.02.014.

7. Baumeister, R. F., Smart, L., \& Boden, J. M. (1996). Relation of threatened egotism to violence and aggression: The dark side of high self-esteem. Psychological review, 103(1), 5-33. Available at: https://psycnet.apa.org/doi/10.1037/0033-295X.103.1.5.

8. Braun, S. (2017). Leader narcissism and outcomes in organizations: a review at multiple levels of analysis and implications for future research. Frontiers in Psychology, 8(773). doi:10.3389/fpsyg.2017.00773.

9. Brender-Ilan, Y., \& Sheaffer, Z. (2019). How do self-efficacy, narcissism and autonomy mediate the link between destructive leadership and counterproductive work behaviour. Asia Pacific Management Review, 24(3), 212-222. https://doi.org/10.1016/j.apmrv.2018.05.003.

10.Bushman, B. J., \& Baumeister, R. F. (1998). Threatened egotism, narcissism, self-esteem, and direct and displaced aggression: Does self-love or self-hate lead to violence? Journal of Personality and Social Psychology, 75(1), 219. Available at: https://psycnet.apa.org/doi/10.1037/0022-3514.75.1.219.

11.Campbell, S., Greenwood, M., Prior, S., Shearer, T., Walkem, K., Young, S., Walker, K. (2020). Purposive sampling: complex or simple? Research case examples. Journal of Research in Nursing, 1-10. https://doi.org/10.1177\%2F1744987120927206.

12.Chen, \& Wang, C.-H. (2019). Incivility, satisfaction and turnover intention of tourist hotel chefs: Moderating effects of emotional intelligence. International Journal of Contemporary Hospitality Management, 31(5), 2034-2053. https://doi.org/10.1108/IJCHM-02-2018-0164.

13.Chughtai, M. S. (2017). Hrm Practices and Employee's Performance: Moderating Role of Islamic Work Ethics and Mediating Role of $\mathrm{Hr}$ Outcomes in Judiciary of Punjab, Pakistan. Virtual University of Pakistan. DOI:10.13140/RG.2.2.15382.19520.

14.Chughtai, M. S., \& Ali Shah, S. Z. (2020). A Moderated Mediation Model: Mediating Mechanism of Workplace Incivility and Moderating Role of Islamic Work Ethics between Dark Triad and Organizational Citizenship Behavior. Management Issues in Healthcare System, 6(1), 1-17. DOI:10.33844/mihs.2020.60233.

15.Chughtai, M. S., Maeenuddin, Ayesha, S., Hafeez, M., Hussain, A., \& Wahid, D. N. (2020). A Moderated Mediation Model of Dark Triad and Organizational Citizenship Behavior: Roles of Workplace Incivility 
and Islamic Work Ethics. International Journal of Advanced Science and Technology, 29(8s), 264-278. Available at: http://sersc.org/journals/index.php/IJAST/article/view/10501.

16.Cohen, A. (2016). Are they among us? A conceptual framework of the relationship between the dark triad personality and counterproductive work behaviors (CWBs). Human Resource Management Review, 26(1), 69-85. https://doi.org/10.1016/j.hrmr.2015.07.003.

17.Cortina, L. M., \& Magley, V. J. (2009). Patterns and profiles of response to incivility in the workplace. Journal of Occupational Health Psychology, 14(3), 272-288. Available at: https://psycnet.apa.org/doi/10.1037/a0014934.

18.Cortina, L. M., Magley, V. J., Williams, J. H., \& Langhout, R. D. (2001). Incivility in the workplace: incidence and impact. Journal of Occupational Health Psychology, 6(1), 64-80. https://doi.org/10.1037/1076-8998.6.1.64.

19.Costello, B. J., \& Dunaway, R. G. (2003). Egotism and delinquent behavior. Journal of Interpersonal Violence, 18(5), 572-590. https://doi.org/10.1177\%2F0886260503251128.

20.De Dreu, C. K., \& Nauta, A. (2009). Self-interest and other-orientation in organizational behavior: implications for job performance, prosocial behavior, and personal initiative. Journal of Applied Psychology, 94(4), 913-926. Available at: https://psycnet.apa.org/doi/10.1037/a0014494.

21.Etikan, I., Musa, S. A., \& Alkassim, R. S. (2016). Comparison of convenience sampling and purposive sampling. American Journal of Theoretical and Applied Statistics, 5(1), 1-4. doi:10.11648/j.ajtas.20160501.11.

22.González-Navarro, P., Zurriaga-Llorens, R., Tosin Olateju, A., \& Llinares-Insa, L. I. (2018). Envy and counterproductive work behavior: The moderation role of leadership in public and private organizations. International Journal of Environmental Research and Public Health, 15(7), 1-17. https://doi.org/10.3390/ijerph15071455.

23.Gulerdg, M. (2020). The Dark Triad and Counterproductive Work Behaviors: Organizational Culture as Moderator. Middle East Technical University. Available at: https://open.metu.edu.tr/bitstream/handle/11511/46144/index.pdf.

24.Harman, D. (1967). A single factor test of common method variance. Journal of Psychology, 35, 359-378. https://doi.org/10.1177\%2F001316446102100437.

25.Hayati, K., Yuningsih, Y., \& Caniago, I. (2018). Can Islamic Work Ethics and Ethical Climate Reduce Counterproductive Work Behavior? International Journal of Economics, Business, and Entrepreneurship, 1(2), 95-101. Available at: http://ijebe.com/journal/index.php/ijebe/article/view/46/13.

26.Hayes, A. F. (2018). Introduction to Mediation, Moderation, and Conditional Process Analysis (Second Edition ed.). New York: The Guilford Press. Available at: https://www.guilford.com/books/Introductionto-Mediation-Moderation-and-Conditional-Process-Analysis/Andrew-Hayes/9781462534654.

27.Jakobwitz, S., \& Egan, V. (2006). The dark triad and normal personality traits. Personality and Individual Differences, 40(2), 331-339.https://doi.org/10.1016/j.paid.2005.07.006.

28.Jones, \& Paulhus. (2011). The role of impulsivity in the Dark Triad of personality. Personality and Individual Differences, 51(5), 679-682. DOI:10.1016/j.paid.2011.04.011.

29.Jones, \& Paulhus. (2014). Introducing the short dark triad (SD3) a brief measure of dark personality traits. Assessment, 21(1), 28-41. https://doi.org/10.1177\%2F1073191113514105.

30.Karim, J., Bibi, Z., Rehman, S. U., \& Khan, M. S. (2015). Emotional intelligence and perceived workrelated outcomes: Mediating role of workplace incivility victimization. Pakistan Journal of Psychological Research, 30(1), 21-37. Available at: http://www.pjprnip.edu.pk/index.php/pjpr/article/view/508/440.

31.Khalid, M., Bashir, S., Khan, A. K., \& Abbas, N. (2018). When and how abusive supervision leads to knowledge hiding behaviors. Leadership \& Organization Development Journal, 39(6), 794-806. https://doi.org/10.1108/LODJ-05-2017-0140.

32.Konrath, S., Bushman, B. J., \& Campbell, W. K. (2006). Attenuating the link between threatened egotism and aggression. Psychological Science, 17(11), 995-1001. https://doi.org/10.1111\%2Fj.14679280.2006.01818.x.

33.Lata, M., \& Chaudhary, R. (2020). Dark Triad and instigated incivility: The moderating role of workplace spirituality. Personality and Individual Differences, 166. https://doi.org/10.1016/j.paid.2020.110090.

34.Leiter, M. P., Laschinger, H. K. S., Day, A., \& Oore, D. G. (2011). The impact of civility interventions on employee social behavior, distress, and attitudes. Journal of Applied Psychology, 96(6), 1258-1274. Available at: https://psycnet.apa.org/doi/10.1037/a0024442.

35.Lim, S., Cortina, L. M., \& Magley, V. J. (2008). Personal and workgroup incivility: Impact on work and health outcomes. Journal of Applied Psychology, 93(1), 95-107. Available at: https://psycnet.apa.org/doi/10.1037/0021-9010.93.1.95. 
36.Liu, P., Xiao, C., He, J., Wang, X., \& Li, A. (2020). Experienced workplace incivility, anger, guilt, and family satisfaction: The double-edged effect of narcissism. Personality and Individual Differences, 154. https://doi.org/10.1016/j.paid.2019.109642.

37.Mackey, J.D., Bishoff, J.D., Daniels, S.R., Hochwarter, W.A., \& Ferris, G.R. (2019). Incivility's relationship with workplace outcomes: Enactment as a boundary condition in two samples. Journal of Business Ethics, 155(2), 513-528. DOI:10.1007/s10551-017-3492-8.

38.Mohammad, J., Quoquab, F., \& Omar, R. (2016). Factors affecting organizational citizenship behavior among Malaysian bank employees: The moderating role of islamic work ethic. Procedia-Social and Behavioral Sciences, 224, 562-570. https://doi.org/10.1016/j.sbspro.2016.05.440.

39.Nasution, F.N., \& Rafiki, A. (2019). Islamic work ethics, organizational commitment and job satisfaction of Islamic banks in Indonesia. RAUSP Management Journal. doi:https://doi.org/10.1108/RAUSP-01-2019$\underline{0011 .}$

40.O'Boyle, E.H., Forsyth, D.R., Banks, G.C., \& McDaniel, M.A. (2012). A meta-analysis of the Dark Triad and work behavior: a social exchange perspective. Journal of Applied Psychology, 97(3), 557-579. doi:10.1037/a0025679.

41.Özsoy, E. (2018). Dark Triad and Counterproductive Work Behaviors: Which of the Dark Triad Traits is More Malevolent? İsletme Araştırmaları Dergisi, 10(4), 742-756. DOI:10.20491/isarder.2018.546.

42.Paulhus, D.L., \& Williams, K.M. (2002). The dark triad of personality: Narcissism, Machiavellianism, and psychopathy. Journal of Research in Personality, 36(6), 556-563. https://doi.org/10.1016/S00926566(02)00505-6.

43.Pearson, C.M., \& Porath, C.L. (2005). On the nature, consequences and remedies of workplace incivility: No time for "nice"? Think again. Academy of Management Perspectives, 19(1), 7-18. https://doi.org/10.5465/ame.2005.15841946.

44.Penney, L.M., \& Spector, P.E. (2002). Narcissism and counterproductive work behavior: Do bigger egos mean bigger problems? International Journal of Selection and Assessment, 10(1-2), 126-134. https://doi.org/10.1111/1468-2389.00199.

45.Porath, \& Pearson, C. (2013). The price of incivility. Harvard Business Review, 91(1-2), 115-121. Available at: https://qualitymanagementinstitute.com/images/hrsolutions/HBR-ThePriceofIncivility.pdf.

46.Qayyum, A., Kousar, S., Jamil, R.A., \& Sarmad, M. (2018). Relationship between Work-Family and Interpersonal Conflicts: Mediating Role of Psychological Distress and the Moderating Effect of Islamic Work Ethics. Journal of Islamic Business and Management, 8(2), 501-519. https://doi.org/10.26501/jibm/2018.0802-010.

47.Quoquab, F., \& Mohammad, J. (2013). Work ethics from the viewpoint of different religious faiths: do they talk the same? Journal of Applied Sciences Research, 9(9), 5436-5452. Available at: https://www.academia.edu/30361821/Work Ethics from the Viewpoint of Different Religious Faiths Do_They_Talk_the_Same.

48.Rizk, R.R. (2008). Back to basics: an Islamic perspective on business and work ethics. Social Responsibility Journal, 4(1/2), 246-254. https://doi.org/10.1108/17471110810856992.

49.Schilpzand, P., De Pater, I. E., \& Erez, A. (2016). Workplace incivility: A review of the literature and agenda for future research. Journal of Organizational Behavior, 37, S57-S88. https://doi.org/10.1002/job.1976.

50.Sguera, F., Bagozzi, R.P., Huy, Q.N., Boss, R.W., \& Boss, D.S. (2016). Curtailing the harmful effects of workplace incivility: The role of structural demands and organization-provided resources. Journal of Vocational Behavior, 95, 115-127. https://doi.org/10.1016/j.jvb.2016.08.004.

51.Shin, Y., \& Hur, W.-M. (2019). Supervisor Incivility and Employee Job Performance: The Mediating Roles of Job Insecurity and Amotivation. The Journal of Psychology, 154(1), 38-59. https://doi.org/10.1080/00223980.2019.1645634.

52.Simonet, D.V., Tett, R.P., Foster, J., Angelback, A.I., \& Bartlett, J.M. (2018). Dark-side personality trait interactions: Amplifying negative predictions of leadership performance. Journal of Leadership \& Organizational Studies, 25(2), 233-250. https://doi.org/10.1177\%2F1548051817727703.

53.Smith, Hill, A.D., Wallace, J.C., Recendes, T., \& Judge, T.A. (2018). Upsides to dark and downsides to bright personality: A multidomain review and future research agenda. Journal of Management, 44(1), 191-217. https://doi.org/10.1177\%2F0149206317733511.

54.Sobel, M.E. (1982). Asymptotic Confidence Intervals for Indirect Effects in Structural Equation Models. Sociological Methodology, 13, 290. doi:10.2307/270723. 
55.Spector, P.E., \& Fox, S. (2002). An emotion-centered model of voluntary work behavior: Some parallels between counterproductive work behavior and organizational citizenship behavior. Human Resource Management Review, 12(2), 269-292. https://doi.org/10.1016/S1053-4822(02)00049-9.

56.Spector, P.E., \& Fox, S. (2005). The Stressor-Emotion Model of Counterproductive Work Behavior Counterproductive work behavior: Investigations of actors and targets (S. Fox \& P. E. Spector ed., pp. 151-174): American Psychological Association. Available at: https://psycnet.apa.org/doi/10.1037/10893-007.

57.Spector, P.E., Fox, S., Penney, L.M., Bruursema, K., Goh, A., \& Kessler, S. (2006). The dimensionality of counterproductivity: Are all counterproductive behaviors created equal? Journal of Vocational Behavior, 68(3), 446-460. https://doi.org/10.1016/j.jvb.2005.10.005.

58.Stenason, L. (2014). Implicit and Explicit Self-Esteem in Relation to the Dark Triad. Western Undergraduate Psychology Journal, 2(1), 1-15. Available at: http://indianmentalhealth.com/pdf/2018/vol5-issue1/Original-Research-Article-5.pdf.

59.Suryanto, T. (2016). Islamic work ethics and audit opinions: Audit professionalism and dysfunctional behavior as intervening variables. Al-Iqtishad: Jurnal Ilmu Ekonomi Syariah, 8(1), 49-64. http://dx.doi.org/10.15408/aiq.v8i1.2508.

60.Victor, B., \& Cullen, J.B. (1987). A theory and measure of ethical climate in organizations. Research in corporate social performance and policy, 9(1), 51-71. Available at: https://archive.org/details/businessethicsre0000unse m4b1/page/n5/mode/2up.

61.Victor, B., \& Cullen, J.B. (1988). The organizational bases of ethical work climates. Administrative Science Quarterly, 33(1), 101-125. https://doi.org/10.2307/2392857.

62.Volmer, J., Koch, I. K., \& Göritz, A. S. (2016). The bright and dark sides of leaders' dark triad traits: Effects on subordinates' career success and well-being. Personality and Individual Differences, 101, 413-418. https://doi.org/10.1016/j.paid.2016.06.046.

63.Wahab, M.A., Quazi, A., \& Blackman, D. (2016). Measuring and validating Islamic work value constructs: An empirical exploration using Malaysian samples. Journal of Business Research, 69(10), 4194-4204. https://doi.org/10.1016/j.jbusres.2016.03.005.

64.Wahyuningsih, W., Nurzaman, M.S., \& Banu, M. (2019). Individual Characteristics, Islamic Work Values, And Organizational Commitment among Islamic Hotel Employees in Lombok Island, Indonesia. Paper presented at the International Conference of Ethics on Business, Economics, and Social Science (ICEBESS 2018). https://dx.doi.org/10.2991/icebess-18.2019.23.

65.Wang, Y.-D., \& Hsieh, H.-H. (2013). Organizational ethical climate, perceived organizational support, and employee silence: A cross-level investigation. Human Relations, 66(6), 783-802. https://doi.org/10.1177\%2F0018726712460706.

66.Welbourne, J.L., \& Sariol, A.M. (2017). When does incivility lead to counterproductive work behavior? Roles of job involvement, task interdependence, and gender. Journal of Occupational Health Psychology, 22(2), 194-206. Available at: https://psycnet.apa.org/doi/10.1037/ocp0000029.

67.Wu, J., \& Lebreton, J.M. (2011). Reconsidering the dispositional basis of counterproductive work behavior: The role of aberrant personality. Personnel Psychology, 64(3), 593-626. https://doi.org/10.1111/j.17446570.2011.01220.x. 
Appendix. QUESTIONNAIRE

\section{Demographics}

1. Gender [ ] Male [ ] Female

2. Age (in years) $20-30[$ ] $31-40[$ ] $41-50[$ ] $51-60[$ ]

3. Level of education

$\mathrm{PhD}$ [ ] M.Phil. [ ] Master's Degree [ ] Graduation [ ] Intermediate [ ] Matric [ ]

\section{Job Title}

Office Coordinator [ ] Senior Office Coordinator [ ] Admin Office Coordinator [ ]

\section{How long have you been working for the Lahore High Court?}

Less than 1 year [ ] 1-5 [ ]6-10 [ ]11-15 [ ] 16-20 [ ] 21 and above [ ]

6. Where do you work in High Court?

Lahore [ ] Rawalpindi [ ] Multan [ ] Bahawalpur [ ]

Instructions: Please answer the following statements by placing a " $\checkmark$ " in the block that will most accurately reflect your opinion about your professional experience.

Table 1. Dark Triad Questionnaire

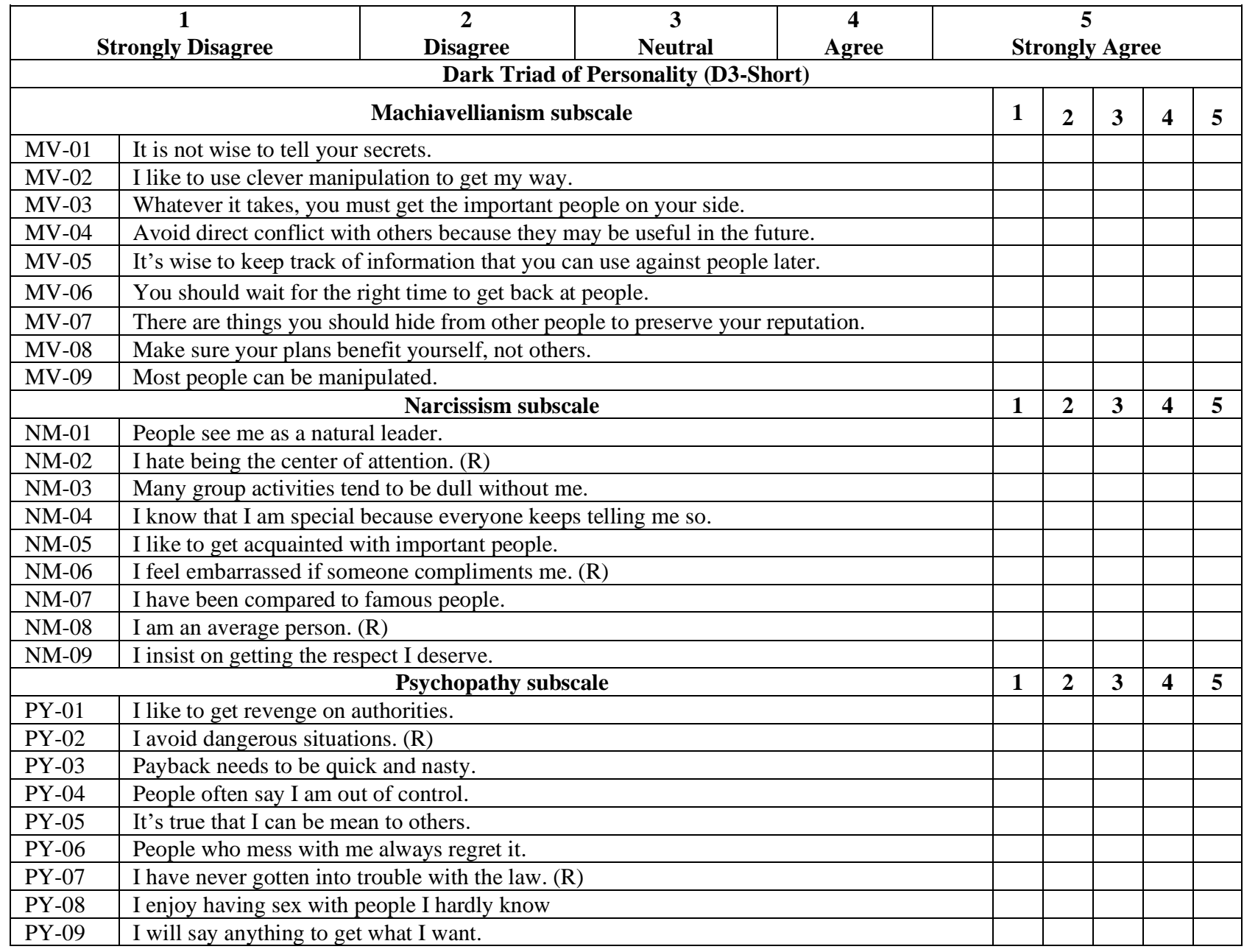

Source: Jones \& Paulhus (2014)

Instructions: Please answer the following statements by placing a " $\checkmark$ " in the block that will most accurately reflect your opinion about your professional experience.

Table 2. Counterproductive Work Behavior Questionnaire

\begin{tabular}{|c|c|c|c|c|c|c|c|c|}
\hline $\begin{array}{c}1 \\
\text { Never }\end{array}$ & $\begin{array}{c}2 \\
\text { Once or Twice }\end{array}$ & $\begin{array}{c}3 \\
\text { Once or Thrice } \\
\text { Per Month }\end{array}$ & $\begin{array}{c}4 \\
\text { Once or Thrice } \\
\text { Per Week }\end{array}$ & \multicolumn{5}{|c|}{$\begin{array}{c}5 \\
\text { Every Day }\end{array}$} \\
\hline \multicolumn{9}{|c|}{ Counterproductive Work Behaviors } \\
\hline \multicolumn{4}{|c|}{ Withdrawal } & 1 & 2 & 3 & 4 & 5 \\
\hline CWB-01 & \multicolumn{3}{|c|}{ Came to work late without permission. } & & & & & \\
\hline CWB-02 & \multicolumn{3}{|c|}{ Stayed home from work and said you were sick when you were not. } & & & & & \\
\hline
\end{tabular}


Table 2 (cont.). Counterproductive Work Behavior Questionnaire

\begin{tabular}{|c|c|c|c|c|c|c|}
\hline CWB-03 & Taken a longer break than you could take. & & & & & \\
\hline CWB-04 & Left work earlier than you could. & & & & & \\
\hline \multicolumn{2}{|r|}{ Abuse } & 1 & 2 & 3 & 4 & 5 \\
\hline CWB-05 & Told people outside the job what a lousy place you work for & & & & & \\
\hline CWB-06 & Started or continued a damaging or harmful rumor at work & & & & & \\
\hline CWB-07 & Been nasty or rude to a client or customer & & & & & \\
\hline CWB-08 & Insulted someone about their job performance & & & & & \\
\hline CWB-09 & Made fun of someone's personal life & & & & & \\
\hline CWB-10 & Ignored someone at work & & & & & \\
\hline CWB-11 & Blamed someone at work for error you made & & & & & \\
\hline CWB-12 & Started an argument with someone at work & & & & & \\
\hline CWB-13 & Verbally abused someone at work & & & & & \\
\hline CWB-14 & Made an obscene gesture (the finger) to someone at work & & & & & \\
\hline CWB-15 & Threatened someone at work with violence & & & & & \\
\hline CWB-16 & Threatened someone at work, but not physically & & & & & \\
\hline CWB-17 & Said something obscene to someone at work to make them feel bad & & & & & \\
\hline CWB-18 & Did something to make someone at work look bad & & & & & \\
\hline CWB-19 & Played a mean prank to embarrass someone at work & & & & & \\
\hline CWB-20 & Looked at someone at work's private mail/property without permission & & & & & \\
\hline CWB-21 & Hit or pushed someone at work & & & & & \\
\hline CWB-22 & Insulted or made fun of someone at work & & & & & \\
\hline
\end{tabular}

Source: Spector et al., 2006

Instructions: Please answer the following statements by placing a " $\checkmark$ " in the block that will most accurately reflect your opinion about your professional experience.

Table 3. Workplace Incivility Questionnaire

\begin{tabular}{|c|c|c|c|c|c|c|c|c|c|}
\hline \multicolumn{2}{|c|}{$\begin{array}{c}1 \\
\text { Strongly Disagree }\end{array}$} & $\begin{array}{c}2 \\
\text { Disagree }\end{array}$ & $\begin{array}{c}3 \\
\text { Neutral } \\
\end{array}$ & $\begin{array}{c}4 \\
\text { Agree }\end{array}$ & \multicolumn{5}{|c|}{$\begin{array}{c}5 \\
\text { Strongly Agree }\end{array}$} \\
\hline \multicolumn{5}{|c|}{ Workplace Incivility } & 1 & 2 & 3 & 4 & 5 \\
\hline WPI-01 & \multicolumn{4}{|c|}{ Put you down or was condescending to you? } & & & & & \\
\hline WPI-02 & \multicolumn{4}{|c|}{ Paid little attention to your statement or showed little interest in your opinion } & & & & & \\
\hline WPI-03 & \multicolumn{4}{|c|}{ Made demeaning or derogatory remarks about you } & & & & & \\
\hline WPI-04 & \multicolumn{4}{|c|}{ Addressed you in unprofessional terms, either publicly or privately } & & & & & \\
\hline WPI-05 & \multicolumn{4}{|c|}{ Ignored or excluded you from professional camaraderie } & & & & & \\
\hline WPI-06 & \multicolumn{4}{|c|}{ Doubted your judgment on a matter over which you have responsibility } & & & & & \\
\hline WPI-07 & \multicolumn{4}{|c|}{ Made unwanted attempts to draw you into a discussion of personal matters? } & & & & & \\
\hline
\end{tabular}

Source: Cortina et al., 2001

Instructions: Please answer the following statements by placing a " $\checkmark$ " in the block that will most accurately reflect your opinion about your professional experience.

Table 4. Islamic Work Values Questionnaire

\begin{tabular}{|c|c|c|c|c|c|c|c|c|c|}
\hline \multicolumn{2}{|c|}{$\begin{array}{c}1 \\
\text { Strongly Disagree }\end{array}$} & $\begin{array}{c}2 \\
\text { Disagree }\end{array}$ & $\begin{array}{c}3 \\
\text { Neutral }\end{array}$ & $\begin{array}{c}4 \\
\text { Agree }\end{array}$ & \multicolumn{5}{|c|}{$\begin{array}{c}5 \\
\text { Strongly Agree }\end{array}$} \\
\hline \multicolumn{10}{|c|}{ Islamic Work Values } \\
\hline \multicolumn{5}{|c|}{ Benevolence (Ihsan) } & 1 & 2 & 3 & 4 & 5 \\
\hline IWV-01 & \multicolumn{9}{|c|}{ I work hard to perform my tasks because I know that God is constantly watching me. } \\
\hline IWV-02 & \multicolumn{9}{|c|}{ Even if I am competent, I will not stop looking for ways to improve myself. } \\
\hline IWV-03 & \multicolumn{9}{|c|}{ I always try to find better, faster and more efficient ways to do things. } \\
\hline IWV-04 & \multicolumn{9}{|c|}{ I would feel bad if I am not doing my job any better than I was previously. } \\
\hline IWV-05 & \multicolumn{9}{|c|}{ I commit myself to continuously improve my performance. } \\
\hline IWV-06 & \multicolumn{8}{|c|}{ I often put in extra effort in my work. } & \\
\hline \multicolumn{5}{|c|}{ Cooperation (Ta'awun) } & 1 & 2 & 3 & 4 & 5 \\
\hline IWV-07 & \multicolumn{4}{|c|}{ I always try to help others. } & & & & & \\
\hline IWV-08 & \multicolumn{4}{|c|}{ Do you cooperate well with your colleagues at work? } & & & & & \\
\hline IWV-09 & \multicolumn{4}{|c|}{ Working with others is better than working alone. } & & & & & \\
\hline IWV-10 & \multicolumn{4}{|c|}{ I am always ready to help those around me. } & & & & & \\
\hline IWV-11 & \multirow{2}{*}{\multicolumn{4}{|c|}{$\begin{array}{l}\text { I am willing to sacrifice my personal interest for the benefit of my coworkers. } \\
\text { Cooperation is a virtue in work. }\end{array}$}} & & & & & \\
\hline IWV-12 & & ork. & & & & & & & \\
\hline
\end{tabular}

Source: Wahab et al. (2016) 